[Podmore, V. (2004). Collectivism, Communities, and Constellations: Some Reflections on Early Childhood Innovations 2003. New Zealand Annual Review of Education, 13, 189-204]

\section{Collectivism, Communities, and Constellations: Some Reflections on Early Childhood Innovations 2003}

\section{VALERIE PODMORE}

\section{Abstract:}

This article identifies some themes and issues from early childhood education policy, research, pedagogy, and practice in Aotearoa 2003. It weaves together some selected themes from the Eighth Early Childhood Convention, held in Palmerston North in September 2003, together with reflections on the concept and development of early childhood centres of innovation (COIs). There is a focus on collaborative, innovative practice and research.

$\mathrm{O}$ ne highlight for early childhood education in 2003 was the Early Childhood Convention, a four-yearly landmark conference for early childhood, held in Palmerston North in September. A number of key themes and issues are evident across the research and policy papers that were presented at the convention (see also May, 2004). Themes and topics selected for consideration in this paper include: pathways or constellations to guide or navigate policy and practices; centres of innovation and/or excellence; communities of learners and communities of practice; and collectivism and/or individualism in early childhood learning and teaching.

The overarching policy initiative for early childhood education in New Zealand during the year under review was the implementation of Pathways to the Future: Ngā Huarahi Arataki, the Government's ten-year plan for early childhood education policy (Ministry of Education, 2002a). Clearly, it is too early to review the implementation and uptake to date of all of the comprehensive policies contained in the plan. ${ }^{1}$ The focus of the present paper is to reflect on one initiative, the "early childhood education centres of innovation", and to connect, discuss, and develop some themes from the research reported in 2003 and presented at the Eighth Early Childhood Convention.

\section{Early Childhood Education Centres of Innovation (COIs)}

The Early Childhood Education Centres of Innovation Programme was implemented as part of Pathways to the Future: Ngā Huarahi Aratak (Ministry of Education, 2002a), and is closely connected to two of its overall goals pertaining to quality and collaboration. The specific objectives of the programme are to contribute to improving quality in the early childhood services by highlighting competent practices in early childhood education, and by publicly presenting action research related to these quality practices (Meade, 2003, October).

The first major step in the implementation of the Centres of Innovation (COI) policy was the selection of six centres. It was intended that the successfully selected COIs would undertake certain responsibilities for a period of three years. Further centres will be selected for later cycles. Their stated responsibilities are:

- To develop and document innovative learning and teaching practices using Te Whaariki;

- To work with researchers to find out what children gain from these innovations;

- To share information with others about their innovative learning and teaching practices.

(Ministry of Education, 2002b)

A suitable definition of innovation was developed for the purposes of assisting the centre personnel prepare their (centre) applications:

Innovation means learning and teaching practices that are different in an identifiable way from typical programmes. Centre staff and management will need to be able to explain the special characteristic/s of their approach to EC learning and teaching processes. (Ministry of Education mimeo, 2003, cited by Meade, 2003, October, p. 4)

Several special characteristics were deemed important in the selection of the six COIs. They included:

Competent practice in teaching and learning in: Kaupapa Maori services, Pasifika immersion and bilingual services, services that 
integrate IT and ICT into the curriculum, and "Community of learning" approaches evident in the collaborative relationships with parents and whanau, and with other programmes, agencies and/or schools. (Ministry of Education, 2003, p. 1 of 1)

The Ministry of Education also publicised widely the information that teachers and educators in the six COIs would work with research associates to investigate, document, and disseminate the characteristics that give their centres a reputation for "effectiveness".

In late 2002, representatives of around seventy centres submitted an expression of interest in having their centre become an early childhood COI. Twelve of the initial applicants who met the essential criteria were then short-listed and invited to prepare detailed proposals. In May 2003, the Minister of Education announced the selection of six early childhood education Centres of Innovation. These current COIs include a childcare centre, a kohanga reo, a Pasifika immersion centre, a playcentre, and two kindergartens, as follows:

- A'oga Fa'a Samoa (Auckland)

- New Beginnings Pre-school (Christchurch)

- Roskill South Kindergarten (Auckland)

- Te Kohanga Reo o Puau Te Moananui-a-Kiwa (East Auckland)

- Wilton Playcentre (Wellington)

- Wycliffe Nga Tamariki Kindergarten (Napier).

Each of the selected COIs focuses on innovations related to: improving links between families and services and among different services; the use of information and computing technology; and/or quality teaching and learning in Maori and Pasifika language immersion services.

Dr Anne Meade, who further developed and implemented the overall COI programme, continues to co-ordinate it nationally. At each of the six COIs, teachers or educators are working alongside their chosen research associate/s, using action research approaches to document their innovation and to reflect on aspects of children's learning and their own teaching practice. The collaborative research team at each of the six COIs developed detailed research plans. Prior to commencing their research in late 2003, each centre applied for and received ethical approval from the Human Ethics Committee at the tertiary institution (or in one case, research organisation) where their lead research associate is based.

\section{Key Themes and Issues}

\section{Pathways and constellations}

For the next ten years, policy developments in the early childhood sector are expected to focus on Pathways to the Future: Ngā Huarahi Arataki, with its three central goals of:

- increasing participation in quality early childhood education services;

- improving the quality of early childhood education services;

- promoting collaborative relationships.

(Fancy, 2003; Ministry of Education, 2002a, p. 2)

Alongside the release and initial implementation of the report, Mason Durie's (2003) ideas provide some pointers and insights for practitioners and policy makers. Durie presented Te Pae Mahutonga: A Navigational Guide... as the opening keynote address at the Early Childhood Convention. The metaphorical model he developed draws on the constellation of Te Pae Mahutonga (the Southern Cross), and is designed to promote secure identity and optimal outcomes for young Māori children. His perspective is consistent with, and supports, the stated position in Pathways to the Future... that access to high quality early childhood education is important for Māori children.

In addition, Durie notes that there are issues concerning the assessment and the contexts of quality, points out that "a secure cultural identity is critical to healthy child development and can act to protect children", and proposes that quality early child hood education potentially supports children's secure cultural identity:

While it would be unreasonable to expect an early childhood centre to be an anchor for cultural identity or even to be a major contributor, by the same token early childhood education presents an opportunity to reinforce identity through its operating philosophy as well as modes of practice. (p. 10)

In Durie's model, the two pointers of Te Pae Mahutonga (The Southern Cross) represent the qualities of Ngā Manukura (effective leadership) and Te Mana Whakahaere (autonomy). With regard to Te Mana Whakahaere, he explained further the importance of "relative autonomy", that is, striking a balance between national guidelines and social initiatives. This explanation of autonomy may signal the need for harmony and balance between the national policies of Pathways to the 
Future: $N g \bar{a}$ Huarahi Arataki and local initiatives within the kohanga reo movement.

The original Terms of Reference for the Development of a Strategic Plan for Early Childhood stated that the working group was to acknowledge the special relationship that Maori and the Crown have through the Treaty of Waitangi, and the specified key tasks of the strategic plan working group were to include the development of three strands: Maori, Pacific, and "mainstream" (Ministry of Education, 2000/01). Consultation and involvement of Maori remain a critical factor in the implementation of Pathways to the Future... which arose directly from the strategic plan. As Durie comments, the two pointers of effective leadership (Ngā Manukura), and autonomy (Te Mana Whakahaere) "symbolise the two key capacities which underpin progress in positive Māori development" (p. 12).

It is interesting to note that leadership and innovation are currently considered to be some of the key features of the Centres of Innovation programme. Meade ${ }^{2}$ has pointed out that leadership is important within the COIs, and has re-iterated Jillian Rodd's (1994) concept of leadership as encompassing three domains: technical (including curriculum planning and delivery, together with managing groups of children and liaising effectively with adults); conceptual (being analytical, together with using innovations to enhance learning) and interpersonal (operating in a caring way within a community). Meade (2003, October, p. 6) also made the insightful observation that the leaders at the majority of the selected COIs effectively "combine professional resolve and personal humility." In addition, Meade notes that leadership is more collective in specific services and centres, giving the examples of the kohanga reo and playcentre.

In the applications prepared by the six successful COIs, a clear focus on learning and teaching innovations is in itself consistent with Rodd's (1994) notion of "conceptual leadership". Further, the applications of all six COIs certainly emphasise the interpersonal and co-operative aspects of leadership. They include explanations about the centre's "shared responsibility", "collaborative or shared leadership", "community leadership", "team approach", leadershipvia a consultative advisory or focus group, collaborative advocacy and "community leadership", and "leadership that depends on the support of the group". Clearly, Rodd's "interpersonal" domain of leadership is a strength across the successful applications. As well as being consistent with the guiding principles or the kaupapa of several COIs and services, this orientation also seems suggestive of personal humility among those who prepared the applications. Aspects of "technical leadership" are also evident. One centre's application, for example, includes sections on pedagogical leadership, advocacy leadership, community leadership, and conceptual leadership. "Pedagogical leadership" is defined as: "keeping up with new ideas, developing and defining innovative practice, and working collaboratively with staff and families and children on teaching and learning enterprises." ${ }^{3}$

Communities of learners, communities of practice, or ... ?

The publicised special characteristics of each of the six diverse New Zealand Centres of Innovation include their use of a "community of learning approach" (Ministry of Education, 2003, p. 1 of 1). Clearly, the concept of "communities of learners" is embedded in notions of innovative early childhood centre practices. This conceptualisation is certainly supported by current theoretical writing on quality early childhood pedagogy (Cullen, 2004; Fleer, Anning, \& Cullen, 2004; Podmore, 2004).

Communities of learning and practice; communities of inquirers and of understanding

Current understanding of "community of learners and community of practice" is derived in part from burgeoning international socio-cultural research and theoretical writing, which largely stems from the early work of Russian theorist Lev Vygotsky (1978). Prominent North American socio-cultural theorist, Barbara Rogoff (1998, p. 689) interprets human development and learning as "a process of transformation of participation where individuals participate and contribute to ongoing activity." The importance of a community of learners and practice is transparent both in Rogoff's proposition that there are three planes of analysis of socio-cultural activities - the personal, the interpersonal, and the community - and in her emphasis on learning through participation.

Similarly, the concept of "communities of practice" is prominent in the work of Etienne Wenger (1998). Like Rogoff, Wenger emphasises learning through participation, and then proceeds to elaborate on the implications of this focus for individuals, communities, and organisations: 
- For individuals, it means that learning is an issue of engaging in and contributing to the practice of their communities.

- For communities, it means that learning is an issue of refining their practice and ensuring new generations of members.

- For organizations, it means that learning is an issue of sustaining the interconnected communities of practice through which an organization knows what it knows and thus becomes effective and valuable as an organization. (pp. 7-8)

The research and writing on learning through participation and on communities of practice is guided by a "social theory of learning", which interweaves the scholarly traditions of "theories of: social structure, practice, collectivity, identity, power, situated experience, subjectivity, and meaning" (pp. 13-15). Theories of "collectivity" focus on social configurations. These configurations may range from local ones involving families, groups, and networks, to global ones encompassing associations, organisations, states, social classes, and social movements.

In addition to "communities of learners" and "communities of practice", Barbara Jordan's (2003a) ${ }^{4}$ comprehensive literature review further differentiates between "communities of inquirers" and "communities of understanding." As Jordan notes, the notion of "communities of inquirers" is associated with socio-cultural researcher Gordon Wells' work. This includes his continuing reflection on, and collaborative analyses of, his verbal teaching and learning interaction data (Wells, 2001, 2002).

Whereas Rogoff $(1998,2003)$ emphasises participation, Wells (2002, pp. 200-201) focuses on inquiry as an approach to learning, and proposes using two metaphors as tools for thinking. The first metaphor, the "improvable object" refers to objects like a cultural artefact, a theory, or a master plan which a group of students (and/or teachers/researchers) may construct or discuss. The second metaphor, a "spiral of knowing" is a tool for thinking about speaking, writing, and curriculum interaction that integrates experience, information, knowledge building, and understanding, leading to action "Communities of inquiry" are both reflective and questioning. They may include students, teachers, and researchers. Wells supports the importance of partnerships, and "the creation of democratic, self-sustaining communities of inquiry within individual schools and school districts" (p. 209).
The term "communities of understanding" is derived from Angela Anning and Anne Edwards' writing on promoting young children's learning. As part of their British research on early years' education, Anning and Edwards (1999) documented aspects of teachers' work in early childhood centre contexts, and found that shared understanding was important if professionals were to develop a sense of community. They also commented on specific principles associated with successful learning communities. Given their emphasis on teachers' shared understanding, it is predictable that their principles included having a shared understanding of purpose. Other principles were: a collective emphasis on children's learning, collaborative activity, "deprivatised" activity, and evidence of reflective discussion (p. 149).

Joce Nuttall (2003), in a paper on teacher co-construction of curriculum (also presented at the Early Childhood Convention and, like Jordan's research, part of a now completed PhD thesis (Nuttall 2004)), highlighted the relevance of Anning and Edwards' research to early childhood practitioners, who meet challenges as they come to understand (jointly) "the meanings of their work". Nuttall (2003) explicitly connected Anning and Edwards' work in the United Kingdom on "communities of learning" (or "communities of understanding"), together with her own research on teachers" construction of early childhood curriculum, to the COI programme here. This is apparent in the final comments in her paper presented at the Early Childhood Convention:

In New Zealand, recently identified early childhood Centres of Innovation hold out some promise for new ways of exploring how teachers in early childhood settings might meaningfully identify and explore the bases for their professional knowledge. Teaching is highly interpretative work and successful teaching in early childhood depends on successful negotiation of the meaning teachers bring to the construct of "curriculum." (p. 91)

There are arguably more similarities than differences across the terms "communities of learners", "communities of practice", "communities of understanding", and "communities of inquiry" as they are used in educational contexts. All appear potentially applicable to the conceptualisation of centres of innovation as having "communities of learners" approaches to learning and teaching. 
Collaborative relationships with parents and whanau

A scrutiny of the special characteristics considered when the COIs were selected reveals that an important factor in the six centres' success was the evidence they provided of a "community of learning" approach in the "collaborative relationships" they have with parents and whanau, and with other programmes and schools.

Subsequently, several of the COIs gave a conference presentation that summarised aspects of their specific "communities of learners" approaches (Meade et al., 2003). Their presentations endorsed that such approaches are indeed in operation within the COIs. Most appeared to reflect Wenger's (1998) notions of "collectivity", focusing mainly on local communities (parents, families, teacher/educators), but also ranging to the more global aspects (cultures, organisations, and social movements). The COI presentations indicated that shared understanding of a "communities of learners" approach has strong links to the centre's philosophy and culture.

\section{Collectivism and/or individualism?}

Notions of "individualism" and "collectivism" have been applied to educational contexts by Patricia Greenfield (Greenfield \& Cocking, 1994) and Janet Gondalez-Mena (2003). In her keynote address at the Early Childhood Convention, Gondalez-Mena focused on the concepts of "individualism" and "collectivism" in order to reflect on early childhood centre practices and cultural differences.

She reported that cultural psychologist Harry Triandis, who writes extensively on individualism and collectivism, found that around 70 per cent of the world's population are collectivists (Triandis, 1996; Triandis, 1989, cited by Gondalez-Mena, 2003). However, individualistic values remain pervasive in "western" early childhood education practice, particularly in the United States. According to Gondalez-Mena, the understanding of "Developmentally Appropriate Practice" by the National Association for the Education of Young Children (NAEYC) in the United States, and associated practices by early childhood teachers and teacher educators, value and foster independence and autonomy in young children. Her address raised awareness that such a focus on individualism is grounded in the values of a minority of the world's population. In contrast, collectivists value interdependence (Rogoff, 2003) and modesty (Gondalez-Mena, 2003).
Returning again to Wenger's work (1998, p. 3), we might observe that there are innovative questions about what might happen if we place learning "in the context of our lived experience of participation in the world." It is interesting to note that aspects of "collectivism" are clearly apparent in the philosophy and approaches within several of the early childhood Centres of Innovation. For example, Tanya Wendt-Samu offers this thoughtful explanation of the importance of the aiga principle within one centre:

The community that we have via the A'oga Fa'a Samoa has many parallels to the fundamental traditional Samoan institution of the aiga - or the extended family.

The A'oga Fa'a Samoa, like the aiga, is a cultural and social institution that has key positions, each with important roles and responsibilities in relation to the others. The positions or groups that are a part of the A'oga Fa'a Samoa are: the teachers, the management committee; families and their children.

The values that underlie our interactions (as families, teachers, and children) are not unlike those which inform our actions within our different aiga. Values include, for example, service and responsibility (tautua), love and commitment (alofa) and respect (faaaloalo). (Taouma, Wendt-Samu, Podmore, Tapusoa, \&Moananu, 2003, p. 5)

As Gonzales-Mena (2003, p. 18) explains in a footnote to her paper, individualism and collectivism are not mutually exclusive - "most people incorporate elements of both" - and her paper tends to contrast the extremes of a continuum. Further reflection on this continuum is likely to enhance shared understanding of quality collectivist practices, as COIs continue working on action research projects that include work on communities of learning.

\section{Innovation and/or excellence?}

Moving to an international view of designated "quality" early childhood centres, it is interesting to note that in 1997/98 in Britain, an "Early Excellence programme" was implemented with intentions that included the integration of services for young children and families to avoid fragmentation and enhance access, and the pursuit of high quality (excellence) (Pascal, 2002; Whalley \& Whitaker, 2003). The current British Government's education "Strategy to 2006" continues to list as one priority area "providing high quality early education and 
childcare for more children" (Department for Education and Skills, 2002, p. 2).

As a part of a "centre of excellence" symposium presentation at the Early Childhood Convention in New Zealand, Margy Whalley, in collaboration with her team of presenters from England, outlined aspects of the development of the centres of early excellence. She presented summary findings from evaluations, and communicated related insights and experiences from within the Pen Green Leadership Centre. Prior to describing the establishment of a leadership programme at Pen Green, Whalley and Whitaker note:

The rapid expansion and development of Integrated Services for Children and Families has created a huge demand for training and support for those Early Years Practitioners appointed to lead new services. Early childhood settings within the Early Excellence Centre Programme, Neighbourhood Nurseries, and Children's Centres are having to develop their services in an integrated way... (2003, p. 6)

They also point out that, amidst marked changes in staff members' responsibilities, few of the staff at centres had "been offered training or development in leadership and fewer still have effective mentoring, support or supervisory systems in place" (p. 7). Reflecting on the work of the COIs in New Zealand, Whalley commented favourably on the notion of centres of "innovation", but noted that the concept of "excellence" in itself had the potential to place excessive pressure on leaders within selected centres.

Support, leadership, collaborative action research, and related continuing professional development appear crucial to the success of "centres of excellence" and "centres of innovation" programmes. This is consistent with the findings of earlier literature reviews connecting quality early childhood education and reflective teacher practice (Podmore \& Meade, with Kerslake Hendricks, 2000). The approach of using action research to evaluate and document innovations is also in line with the conclusions of the strategic research initiative literature review on early childhood education (Smith, Grima, Gaffney, Powell, Masse, \& Barnett, 2000, p. 124), and with research on effective professional development, "enhanced pedagogy", and children's learning, as documented in a recent, comprehensive "best evidence synthesis" review (Mitchell \& Cubey, 2003).

\section{Concluding Comments}

This article presents evidence that the Centres of Innovation programme is seen, both internationally and within New Zealand, as a key policy initiative to en hance quality learning and teaching in early childhood centres. It also weaves together some themes from the Eighth Early Childhood Convention and issues arising from current theoretical and research-based writing. Reflections on the selected themes of "pathways and configurations"; "communities of learners, communities of practice or ...?"; "collectivism and/or individualism?", and "innovation and/or excellence?" endorse many aspects of the New Zealand conceptualisation of early childhood centres of innovation. There is support for the inspiration of the COI venture. Nevertheless, this review also suggests some challenges for COIs and their research associates as they/we continue to implement and document innovative teaching and learning practices for children in "community of learners" contexts.

In the most recently available press release on the COI policy, Education Minister Trevor Mallard's media statement on February 26, 2004 announced that further funding of $\$ 2$ million will be allocated to three new early childhood Centres of Innovation in 2005. An appropriate conclusion for this article is the rationale for the announcement, which includes these comments:

Centres of Innovation support continuous improvement of early childhood education, encourage provider collaboration, facilitate networks of learning support, build research capability, share information, develop leadership and strengthen quality teaching and learning...

Centres of Innovation are a significant way of improving quality in early childhood education, one of the key goals in Pathways to the Future: Ngā Huarahi Arataki, the early childhood strategic plan, launched in 2002.

The ECE Centres of Innovation programme has shown how vibrant and innovative the early childhood sector is and reflects its commitment to developing the best teaching practice to support effective learning for children. (Mallard, February 23, 2004, p. 1 of 1)

\section{Notes}

1. For an initial overview of key points of the Pathways to the Future:. policies, with reference to discourses on children's rights, see Dalli \& Te One, 2003. 
2. From a guest lecture to EDUC557/457 MEd course, entitled Innovative centre practices and children's learning, given at Victoria University of Wellington, August, 2003.

3. Cited from the application to the Ministry of Education from Roskill South Kindergarten, 2003, released to the author on request.

4. In a recently completed $\mathrm{PhD}$ thesis. Aspects of Barbara Jordan's research were also presented at the Early Childhood Convention - see Jordan, 2003b.

\section{References}

Anning, A., \& Edwards, A. (1999). Promoting children's learning from birth to five: Developing the new early years professional. Buckingham: Open University Press.

Cullen, J. (2004). Adults co-constructing professional knowledge. In A. Anning, J. Cullen, \& M. Fleer (Eds.), Early childhood education: Society and culture (pp. 69-79). London: Sage Publications.

Dalli, C., \& Te One, S. (2003). Early childhood education in 2002: Pathways to the Future. New Zealand Annual Review of Education, 12, 177-202.

Department for Education and Skills. (2002). Education and skills: Delivering results: A strategy to 2006. (Revised December 2002). <www.dfes.gov.uk/research > Retrieved May 18, 2004.

Durie, M. (2003, September). Te pae mahutonga: A navigational guide for the promotion of secure identity and best outcomes for Maori children. Proceedings of the Eighth Early Childhood Convention, Vol. 1 (pp. 9-16). Palmerston North.

Fancy, H. (2003, September 23). Address presented at the Eighth Early Childhood Convention, Palmerston North.

Fleer, M., Anning, A., \& Cullen, J. (2004). A framework for conceptualizing early childhood education. In A. Anning, J. Cullen, \& M. Fleer (Eds.), Early childhood education: Society and culture (pp. 175-189). London: Sage Publications.

Gonzalez-Mena, J. (2003, September). Bridging cultures with understanding and sensitivity. Proceedings of the Eighth Early Childhood Convention, Vol. 1 (pp. 17-26). Palmerston North.

Greenfield, P., \& Cocking, R. R. (Eds.). (1994). Cross-cultural roots of minority child development. Hillsdale, NJ: L. Erlbaum Associates.
Jordan, B. (2003a). Professional development making a difference for children: Co-constructing understandings in early childhood centres. Unpublished PhD thesis, Massey University, Palmerston North.

Jordan, B. (2003b, September). Scaffolding and co-constructing in early childhood: Professional development with teachers as a model for sharing power with children. Paper presented at the Eighth Early Childhood Convention, Palmerston North.

Mallard, T. (2004). Building knowledge for better early childhood learning. Media statement, February 26, 2004

< www.minedu.govt.nz/news and announcements/news story/p.1> Retrieved March 2, 2004.

May, H. (2004). Moving the frontiers of convention 1975-2003; An overview of the early childhood education landscape. New Zealand Annual Review of Education, 13, 169-188.

Meade, A. (2003, October 30). ECE centres of innovation in New Zealand. Paper presented at Leadership and Management in the Early Years Conference, Corby, Northamptonshire, UK.

Meade, A., A'oga Fa'asamoa, New Beginnings Preschool, Wilton Playcentre, \& Wycliffe Nga Tamariki Kindergarten, with their research associates. (2003, November 29). Gathering communities of learners around Centres of Innovation. Seventh Annual Early Childhood Research Network Symposium, Epsom, Auckland.

Ministry of Education. (2000/01). $<$ www.minedu.govt.nz./early childhood/early childhood strategic plan> Retrieved February 28, 2004.

Ministry of Education. (2002a). Pathways to the future: Ngā huarahi arataki. Wellington: Ministry of Education.

Ministry of Education. (2002b). Centres of Innovation package, 2002. <www.minedu.govt.nz>. Retrieved February 28, 2004.

Ministry of Education. ( 2003). $<$ www.minedu.govt.nz/index/early childhood strategic plan/ECE Centres of Innovation/Six Centres of Innovation, p. 1> Retrieved 3 April 2004).

Mitchell, L., \& Cubey, P. (2003). Characteristics of professional development linked to enhanced pedagogy and children's learning in early childhood settings: Best evidence synthesis. Wellington: Ministry of Education and New Zealand Council for Educational Research. 
Nuttall, J. (2003, September). Teacher co-construction of "curriculum" in childcare: The rhetoric and the reality. Proceedings of the Eighth Early Childhood Convention, Vol. 2 (pp. 79-91). Palmerston North.

Nuttall, J. (2004). Why don't you ask someone who cares? Teacher identity, intersubjectivity, and curriculum negotiation in a New Zealand early childcare centre. Unpublished PhD Thesis, Victoria University of Wellington.

Pascal, C. (2002, August). Effective Early Learning: An act of practical learning. Keynote address presented at the European Early Childhood Education Research Association Conference, Lefkosia/Nicosia, Cyprus.

Podmore, V. N. (2004). Questioning evaluation quality in early childhood. In A. Anning, J. Cullen, \& M. Fleer (Eds.), Early childhood education: Society and culture (pp. 147-158). London: Sage Publications.

Podmore, V. N. \& Meade, A., with Kerslake Hendricks, A. (2000). Aspects of quality in early childhood education. Literature Review Series. Wellington: New Zealand Council for Educational Research.

Rodd, J. (1994). Leadership in early childhood education: The pathway to professionalism. St. Leonards, NSW: Allen \& Unwin.

Rogoff, B. (1998). Cognition as a collaborative process. In D. Kuhn \& R. S. Siegler (Eds.), Handbook of Child Psychology, Vol 2: Cognition, Perception, and Language (5th ed.) (pp. 679-744). New York: Wiley.

Rogoff, B. (2003). The cultural nature of human development. New York: Oxford University Press.

Smith, A. B., Grima, G., Gaffney, M., Powell, K., Masse, L., \& Barnett, S. (2000). Strategic research initiative literature review: Early childhood education. Wellington: Ministry of Education, Research Division.

Taouma, J., Wendt-Samu, T., Podmore, V. N., Tapusoa, E., \& Moananu, M. (2003, November). Innovation and collaborative research development in an early childhood centre. Paper presented at the joint NZARE-AARE Conference, Auckland.

Triandis, H. C. (1996). Individualismand collectivism. Boulder: Westview Press.

Vygotsky, L. S. (1978). Mind and society: The development of higher mental processes. Cambridge, MA: Harvard University Press.
Wells, G. (2001). Action, talk and text: Learning through inquiry. New York, NY: Teachers College Press.

Wells, G. (2002). Inquiry as an orientation for learning, teaching and teacher education. In G. Wells \& G. Claxton (Eds.), Learning for life in the 21st century: Sociocultural perspectives on the future of education (pp. 196-210). Oxford, UK: Blackwell Publishers.

Wenger, E. (1998). Communities of practice: Learning, meaning, and identity. Cambridge, UK: Cambridge University Press.

Whalley, M., \& Whitaker, P. (2003, September). The Pen Green Leadership Centre: Developing leadershiplearning and growing learning communities. Paper presented at the Early Childhood Convention, Palmerston North. (55pp).

\section{The author}

Dr Val Podmore is a senior lecturer at the Institute for Early Childhood Studies, and research convenor for the School of Education, at Victoria University of Wellington. She is currently a lead research associate working alongside an early childhood Centre of Innovation in Auckland (2003-2006) on contact to the Ministry of Education (through Victoria Link Ltd.). Her research interests include: early childhood policies, curriculum, and evaluation (national and international); young children's learning and development; research methods and ethics; and socio-cultural approaches and participatory action research.

\section{Acknowledgements}

I am grateful to colleagues who previewed or blind reviewed a draft of this paper. I also warmly acknowledge the six COIs, and the Ministry of Education for funding the early childhood Centres of Innovation research. 